Click www.researchjournal.co.in/online/subdetail.html to purchase.

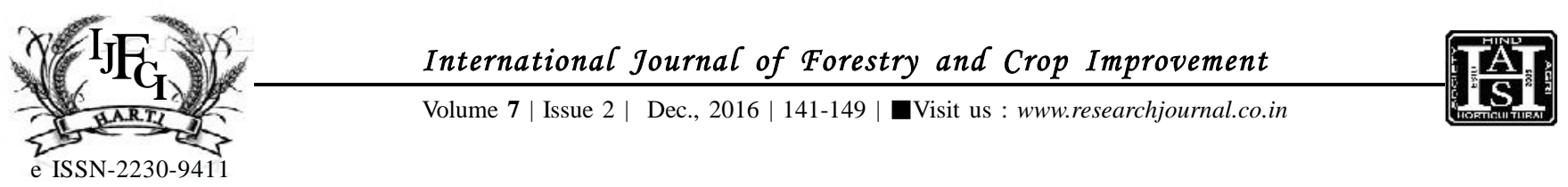

RESEARCH ARTICLE

DOI: $10.15740 / \mathrm{HAS} / \mathrm{IJFCI} / 7.2 / 141-149$

\title{
Efficacy of Qninalphos 25 EC against Antigastra catalaunalis and Asphondylia sesami of sesamum
}

\author{
N.J. JUMALE, P.N. MANE AND F.S. KHAN
}

\begin{abstract}
Experiment was conducted during Kharif 2015 -2016 at field of Department of Agricultural Entomology, Post Graduate Institute, Dr. Panjabrao Deshmukh Krishi Vidyapeeth, Akola, to study efficacy of Qninalphos 25 EC against gall fly and capsule borer of Sesamum. Seasmum crop is attacked by number of insect pest throughout growing season. Leaf roller/capsule borer, Antigastra catalaunalis Dup. and sesamum gall fly is important, as it is regular in occurrence and thus a major pest. Quinalphos is contact and stomach poison having cholinesterase inhibiting action control many insect pests of the orders Lepidoptera, Coleoptera, Diptera and Hemiptera. As per behaviour of these pests it is essential to apply insecticide at proper growth stage of crop to avoid losses. Quinalphos 25 EC @ $2 \mathrm{ml} /$ lit. of water applied at 15, 30 and 45 days after crop emergence therefore prove effective against leaf webber, gall fly and capsule borer.
\end{abstract}

KEY WORDS : Quinalphos 25 EC, Efficacy, Gall fly, Leaf webber, Capsule borer

How TO CITE THIS ARTICLE : Jumale, N.J., Mane, P.N. and Khan, F.S. (2016). Efficacy of Qninalphos 25 EC against Antigastra catalaunalis and Asphondylia sesami of sesamum. Internat. J. Forestry \& Crop Improv., 7 (2) : 141-149, DOI: 10.15740/HAS/IJFCI/7.2/141149.

Article Chronical : Received : 14.06.2016; Revised : 03.11.2016; Accepted : 17.11.2016

Address of the Correspondence : F.S. KHAN, Oilseeds Research Unit, Dr. Panjabrao Deshmukh Krishi Vidyapeeth, AKOLA (M.S.) INDIA

Email: fariakhan.31@ rediffmail.com

Address of the Coopted Authors : N.J. JUMALE, Department of Agricultural Entomology, Dr. Panjabrao Deshmukh Krishi Vidyapeeth, AKOLA (M.S.) INDIA

P.N. MANE, Oilseeds Research Unit, Dr. Panjabrao Deshmukh Krishi Vidyapeeth, AKOLA (M.S.) INDIA

Email: pnmane_ento@rediffmail.com 